\title{
Burkina Faso and Mali: Female genital cutting harms women's health
}

Frontiers in Reproductive Health

Follow this and additional works at: https://knowledgecommons.popcouncil.org/departments_sbsr-rh

Part of the Family, Life Course, and Society Commons, International Public Health Commons, and the Maternal and Child Health Commons

How does access to this work benefit you? Let us know!

\section{Recommended Citation}

"Burkina Faso and Mali: Female genital cutting harms women's health," FRONTIERS OR Summary. Washington, DC: Population Council, 2000. 


\section{Burkina Faso and Mali FGC}

OR Summary 10

\section{Female Genital Cutting Harms Women's Health}

\begin{abstract}
Women in Burkina Faso and Mali who have had their genitals cut are more likely to have gynecological and obstetrical problems, including bleeding, internal scarring, vaginal narrowing, and complications during childbirth. More severe cutting increases a woman's risk of other reproductive health problems.
\end{abstract}

\section{Background}

In collaboration with the Ministries of Health $(\mathrm{MOH})$ of Burkina Faso and Mali, the Population Council conducted two studies in 1998 to describe the occurrence and severity of health problems related to female genital cutting (FGC). This traditional practice entails partial or total removal of girls' external genitalia.

Study participants were consenting women who received a pelvic exam during prenatal, family planning, obstetric, or gynecological consultations at $\mathrm{MOH}$ clinics. Providers were trained to observe the types and complications of FGC. In order to assess their potential role as change agents, providers in Mali also received training on the health effects of FGC and client counseling. In Burkina Faso, health providers recorded information on and interviewed 1,920 women at 21 health centers in the rural provinces of Bazèga and Zoundwèogo. In Mali's Bamako district and Ségou region, providers recorded information on 5,390 women in 14 urban and rural health centers.

\section{Findings}

- The prevalence of FGC was very high - 93 percent of the clinic clients in Burkina Faso and
94 percent in Mali had been cut. In Burkina Faso, Type 1 (removal of the clitoral hood and/ or clitoris) was most common. Nearly threefourths $(74 \%)$ of the women in Mali had Type 2 (clitoridectomy and removal of the labia minora). Five percent of women in both groups had the most severe form of FGC, Type 3 or infibulation, which entails partial or complete removal of the external genitalia with stitching or narrowing of the vaginal opening. FGC was found among all ethnic groups.

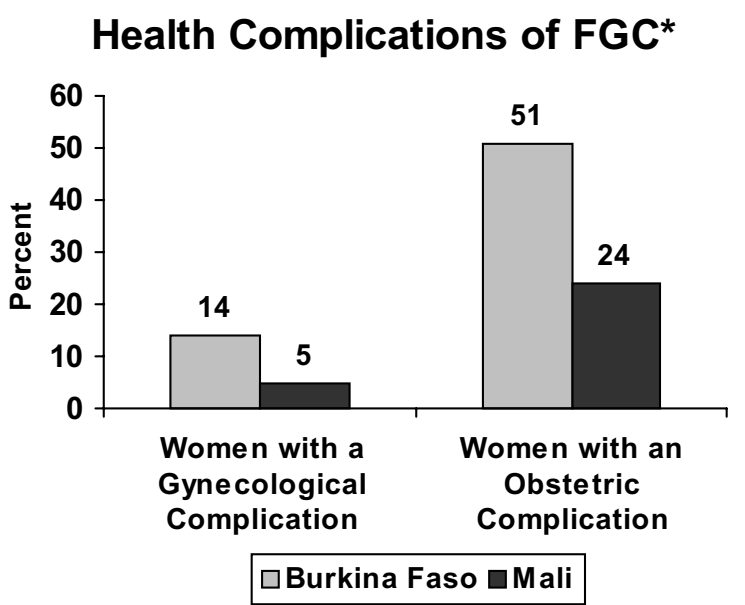

* Based on client reports in Burkina Faso and actual deliveries in Mali. 
- Fourteen percent of the clients in Burkina Faso and 5 percent of those in Mali had at least one gynecological complication related to FGC. In Burkina Faso, where the majority of women have Type 1 cutting, keloid scarring and vaginal stenosis (narrowing of vaginal walls due to scarring) were the major complications reported by women. In Mali, where Type 2 cutting predominates, hemorrhaging from scar tissue was the major complication observed by clinic staff, followed by vaginal scarring and obstruction.

- In both countries, women who were infibulated (Type 3) were almost two and a half times more likely to have a gynecological complication than those with a Type 2 cut. Similarly, women with a Type 1 cut were much less likely to have a complication than those with more severe cuts.

- FGC was found to be a major risk factor for complications during childbirth, with risks increasing according to the severity of the cut. In Burkina Faso, cut women were three times more likely to report having had a difficult delivery than uncut women. Women with Types 2 or 3 cutting were more likely to experience hemorrhaging or perineal tearing during delivery.
- Among the women in Mali who gave birth at the clinic, 29 percent of those who had been cut experienced complications during childbirth, compared with 7 percent among those who had not been cut. In Mali, 5 percent of uncut women experienced complications during delivery compared with 18 percent of women with Type 1 cutting, 30 percent of those with Type 2, and 36 percent of those with Type 3 .

- In Burkina Faso, cut women were 1.5 times more likely than uncut women to show signs of genital infection, particularly vaginal discharge, suggesting that FGC may render women more susceptible to RTIs.

\section{Policy Implications}

All health personnel should receive information on the serious health problems associated with FGC.

- In addition to women's rights issues, information on the deleterious health effects of FGC should be used in community education campaigns.

- People assisting women giving birth should anticipate the possibility of FGC-related complications.

Diop, Nafissatou J., et al. Etude de l'Efficacité de la Formation du Personnel Socio-sanitaire dans l'Education des Client(e)s sur l'Excision au Mali. Bamako, Mali: Population Council, 1998.

Laboratoire de Santé Communautaire du Bazèga. Evaluation de la Prevalence, de la Typologie, et des Complications Liées à l'Excision chez les Patientes Frequentant les Formations Sanitaires du Bazèga. Ougadougu, Burkina Faso: Population Council. 1998.

Jones, Heidi, et al. Female Genital Cutting and its Negative Health Outcomes in Burkina Faso and Mali. Studies in Family Planning Vol. 30, No. 3, September 1999. For more information, contact Population Council, P.O. Box 21027, Dakar, Senegal. Tel. 221-824-1933; Fax 221-824-1998; E-mail: pcdakar@pcdakar.org.

This project was conducted with support from the U.S. AGENCY FOR INTERNATIONAL DEVELOPMENT under Contract Number CCP-3030-C-00-3008-00 and Cooperative Agreement Number HRN-A-00-98-00012-00. 